\title{
Antioxidative Enzyme Responses to Antimony Stress of Serratia marcescens - an Endophytic Bacteria of Hedysarum pallidum Roots
}

\author{
Mounia Kassa-Laouar ${ }^{1}$, Aicha Mechakra ${ }^{1}$, Agnès Rodrigue ${ }^{2}$, Ouissem Meghnous ${ }^{1}$, \\ Alima Bentellis ${ }^{3}$, Oualida Rached ${ }^{3 *}$ \\ ${ }^{1}$ Biology and Environment Laboratory, Faculty of Nature and Life Sciences, Mentouri University Constantine 1, \\ Constantine, Algeria \\ ${ }^{2}$ Laboratory of Microbiology, Adaptation and Pathogeny, University Lyon 1, France \\ ${ }^{3}$ Biotechnology High National School Taoufik Khaznadar, Ali Mendjeli University City, \\ Constantine, Algeria
}

Received: 1 October 2018

Accepted: 4 December 2018

\begin{abstract}
Studies on bacterial endophytes resistant to antimony ( $\mathrm{Sb}$ ), a pollutant deemed alarming, are virtually non-existent. An endophytic bacterial strain showing resistance to high antimony concentrations was isolated for the first time from the roots of Hedysarum pallidum Desf., a Sb accumulator Fabacea growing on mining spoils. With the combined use of morphological, biochemical and molecular methods, the isolated strain was identified as Serratia marcescens species. It showed a minimum inhibitory concentration (MIC) to its growth at $450 \mathrm{mM}$ of Sb. In the presence of excessive concentrations of $\mathrm{Sb}$, corresponding to $30 \mathrm{mM}$ of $\mathrm{Sb}$, i.e., $3652.8 \mathrm{mg} / \mathrm{L}$ of $\mathrm{Sb}$, the strain maintained important growth compared to the control. The Sb toxicity caused a significant increase $(\mathrm{p}<0.05)$ in the hydrogen peroxide $\left(\mathrm{H}_{2} \mathrm{O}_{2}\right)$ amount and malondialdehyde (MDA) content. The oxidative stress induced significant increases $(\mathrm{p}<0.05)$ in the strain antioxidant biomarkers such as proline, catalase (CAT), ascorbate peroxidase (APX), peroxidase (POD) and superoxide dismutase (SOD). Significant and positive correlations $(p<0.05)$ were found between oxidative and antioxidant biomarkers and between antioxidant biomarkers, highlighting the interrelationships between them in oxidative stress fighting. Results show an important adaptation of the strain to high $\mathrm{Sb}$ levels that can be used in the Sb-contaminated soils bioremediation.
\end{abstract}

Keywords: antioxidants; bacteria; endophyte; metalloid; mine spoils

*e-mail: o.rached@ensbiotech.edu.dz 


\section{Introduction}

Antimony, a metalloid of molecular weight 121.75 , is considered a toxic element and pollutant of concern whose increasing emissions are due to industrialization and mining [1, 2]. According to Mubarak et al. [3], the resulting carcinogenicity of such pollution requires the removal of this metalloid from the ecosystem. Therefore, the development of a remediation strategy for antimony-contaminated soils is necessary. Currently, the bioremediation is an effective and inexpensive method of metals elimination $[3,4]$. It involves both plants and the indigenous rhizospheric microflora, such as metaltolerant endophytic bacteria $[5,6]$. This microflora is able to use these pollutants as nutrients for its proliferation [7]. Moreover, it stimulates the growth of its host and gives it a better adaptation to metallic stress $[8,9]$.

The bacterial exposure to high levels of heavy metals results in an overproduction of reactive oxygen species (ROS). This induces the production of antioxidant enzymes such as catalase (CAT), peroxidase (POD), ascorbate peroxidase (APX) and superoxide dismutase (SOD), and non-enzymatic compounds such as proline, which allow for an adaptation of bacteria to environmental stresses [10]. The measurement of these antioxidants makes it possible to highlight the degree of adaptation of bacteria to heavy metals (or metalloids) and therefore their possible use in the bioremediation of soils contaminated by them. Set apart from the description of some resistance mechanisms (efflux pump, methylation, complexation, oxidation-reduction reactions and microbe mediated electron transfert) of bacteria against heavy metals and metalloids, in particular antimony $[11,12]$, the role of the antioxidant system in bacteria towards this metalloid remains poorly described [10].

In northeastern Algerian, a previous study revealed very high $\mathrm{Sb}$ levels in soils surrounding spoils of an old antimony mine (up to $81.446 \mathrm{mg} / \mathrm{kg}$ ) involving modifications of the spontaneous vegetation and the survival of certain resistant plants [13]. This is the case of Hedysarum pallidum Desf., a Fabaceae, which concentrates up to $263 \mathrm{mg} / \mathrm{kg}$ of $\mathrm{Sb}$ in its upper parts and $183 \mathrm{mg} / \mathrm{kg}$ of this element in its underground parts [14]. According to these authors, the adaptation of this plant to high $\mathrm{Sb}$ concentrations resulted in the activation of its antioxidant enzymes such as CAT, SOD, APX and POD.

Such results raise the question whether this plant contains endophytic bacteria in its roots, which have similar antioxidant enzyme activities and allow their host a better tolerance to the high levels of metals. Such bacteria would be potential candidates for bioremediation of antimony-contaminated soils.

The purpose of the present work is to highlight and identify the most antimony-resistant endophytic bacterium from $H$. pallidum roots by determining its MIC. It also aims at determining the tolerance strategy of the resistant species to $\mathrm{Sb}$ by studying the impact of the metalloid on the production of reactive oxygen species, on lipid peroxidation, and on the antioxidant biomarkers.

The objective is also to better understand hostendophyte relationships and antioxidant molecule interactions in the antimony stress fighting.

\section{Experimental}

\section{Sampling Zone Characteristics}

The sampling station is located in the area of an old antimony mine situated on one side of the Djebel Hamimat mountain in northeastern Algeria at an average altitude of $865 \mathrm{~m}\left(35^{\circ} 58^{`} 37,64^{\prime \prime} \mathrm{N}-7^{\circ} 11^{\prime} 22,80^{\prime \prime} \mathrm{E}\right.$ to $36^{\circ} 01^{\circ} 09,78^{\prime \prime} \mathrm{N}-7^{\circ} 14^{`} 38,38 \mathrm{E}$ ) (Fig. 1). In this zone are $\mathrm{Sb}$ occurrences and several large mining excavations whose waste, conveyed by the Dahimine wadi, are the cause of important contamination of the surrounding area. The sampling area is a semi-arid region with steppic vegetation [13].

The sampling was carried out in March 2016 in the most contaminated station of the study area, which presents the following physicochemical properties as determined by previous authors [14]: $62000 \pm 4924 \mathrm{mg} / \mathrm{kg}$ of antimony (Sb), $2300 \pm 186 \mathrm{mg} / \mathrm{kg}$ of arsenic (As), $0.9 \pm 0.04 \%$ of organic matter (OM), $38.7 \pm 1.82 \%$ of $\mathrm{CaCO}_{3}, 23.0 \pm 4.9 \%$ of Clay, $16.3 \pm 1.02 \%$ of Silt, $53.7 \pm 3.22 \%$ of sand and a $\mathrm{pH}$ of $8.01 \pm 0.09$.

\section{Plant Sampling}

In the sampling station (Fig. 1) 8 specimens of H. pallidum were randomly chosen. Roots were extracted with a sterile auger, then taken with sterile gloves and introduced immediately into sterile jars after being separated from the aerial part by sterile scissors.

\section{Endophytic Bacteria Isolation}

The roots underwent superficial sterilization to eliminate epiphytic organisms according to the method described by Deng et al. [4] and Dombrowski et al. [15]. This one consisted in washing the samples under running tap water, followed by sequential treatments with $75 \%(\mathrm{v} / \mathrm{v})$ ethanol for 2 minutes, sodium hypochlorite $(\mathrm{NaOCl})(5 \%)$ for 1 minute and finally rinsing of the roots three times with sterile distilled water for 1 minute.

The roots were then cut into fragments of a few millimeters and placed on Petri dishes containing nutrient agar (NA) ( $\mathrm{pH}$ 7.0) composed of $0.5 \%$ peptone, $0.3 \%$ meat extract, and $1.5 \%$ agar. The NA was supplemented with $10 \mathrm{mg} / \mathrm{L}$ of Amphotericin B (Wolfratshausen, Germany) to inhibit any fungal growth. The dishes were incubated at $30^{\circ} \mathrm{C}$ for one week. Each formed colony was isolated, purified and 

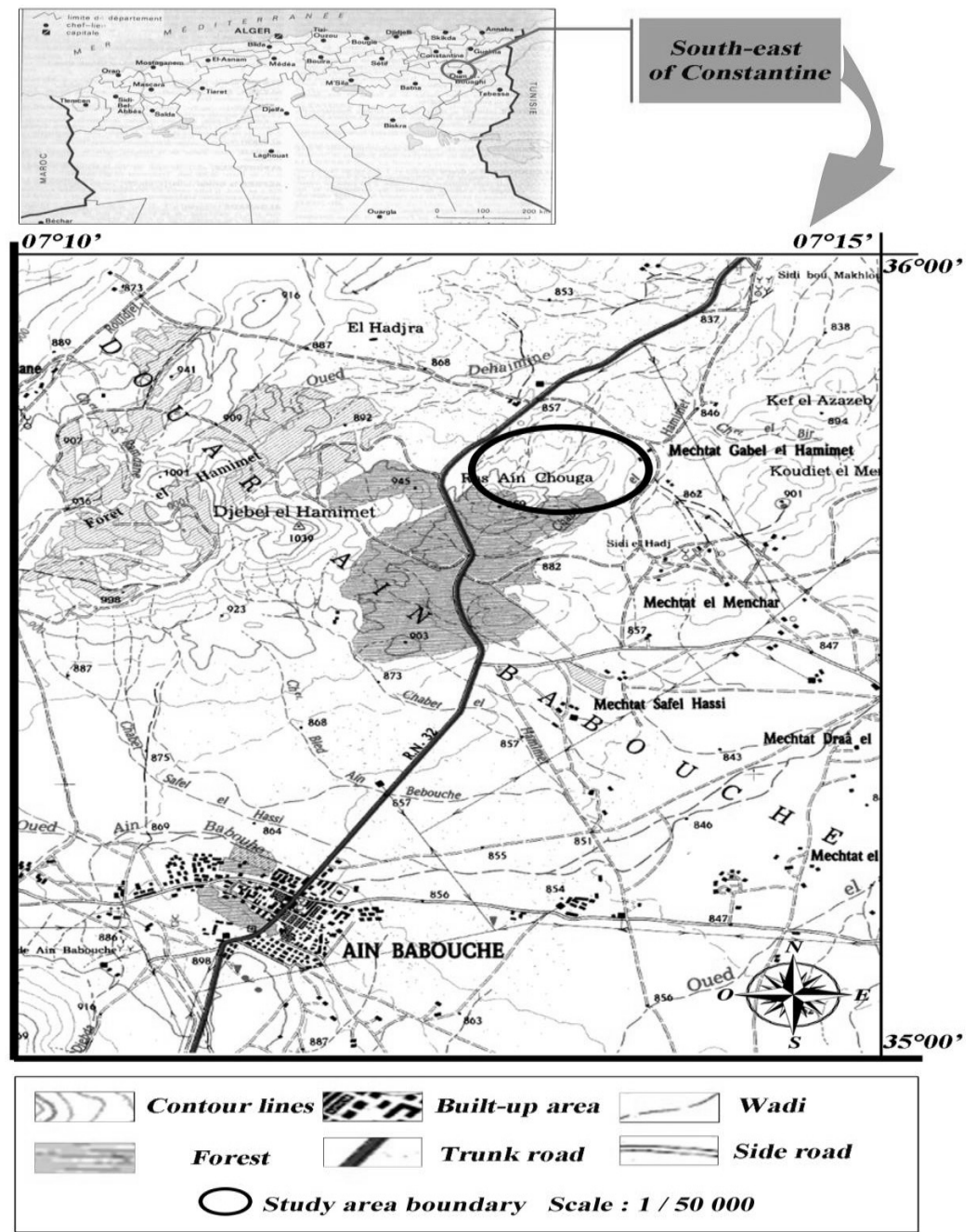

Fig. 1. Study area location.

stored at $4^{\circ} \mathrm{C}$ in Luria-Bertani (LB) containing $20 \%$ (v/v) glycerol.

To check the efficiency of roots disinfection, aliquots of $0.3 \mathrm{~mL}$ of the final rinsing water were spread on Petri dishes of the medium previously mentioned, and incubated under the same conditions as described above. The absence of any microbial growth on this medium indicated that all the isolated bacteria were endophytes [4].

\section{MIC Determination of the Isolated Endophytes}

A screening was performed with increasing doses of $\mathrm{Sb}(5-450 \mathrm{mM})$ on the set of the isolated bacteria, in order to determine their MICs and to highlight one or several antimony-resistant bacteria. For that, $0.5 \mathrm{~mL}$ of $24 \mathrm{~h}$ pre-culture containing approximately $4 \times 10^{5}$ CFU (colony-forming unit) were inoculated in tubes containing $10 \mathrm{~mL}$ of $\mathrm{LB}$ added with different metal concentrations ranging from 5 to $450 \mathrm{mM}$ of $\mathrm{Sb}$ as $\mathrm{C}_{8} \mathrm{H}_{4} \mathrm{~K}_{2} \mathrm{O}_{12} \mathrm{Sb}_{2} 3 \mathrm{H}_{2} \mathrm{O}$. The tubes were incubated in a rotary shaker (New Brunswick Scientific, Co., Inc., NJ and USA) for $24 \mathrm{~h}$ at $30^{\circ} \mathrm{C}$ and $150 \mathrm{rpm}$. The bacterial growth was checked visually by appearance of turbidity in the culture medium. The lowest concentration of the metalloid, which inhibits the bacterial growth and which does not involve any apparent turbidity, was considered MIC [16].

\section{Identification of Selected Sb-Resistant Bacteria}

The identification of the resistant strain was based initially on morphological and physiological characteristics using selective culture media, the Gram staining reaction and the standard biochemical techniques. The isolate was further identified by conventional biochemical tests using the API 20E strips (BioMérieux, Inc. France). In the second step, the molecular identification of this strain was carried. $16 \mathrm{~S}$ rDNA gene was amplified and sequenced using the sense and antisense primers: FD1 (5'-AGAGTTGATCCTGGCTCAG-3') and RP2 (5'-ACGGCTACCTTGTTACGAC-3') (Sigma). These sequences were compared with similar sequences in the gene bank DNA database using BLAST analysis 
(basic logical alignment search tool, at NCBI). Finally, the phylogenetic tree and evolutionary distances were calculated using the MEGA (molecular evolutionary genetic analysis) 7 program.

\section{Determining Oxidative and Antioxidant Biomarkers}

\section{Preparing Bacterial Biomass}

The biomass of the resistant strain was produced in $250 \mathrm{~mL}$ Erlenmeyer flasks containing $50 \mathrm{~mL}$ of LB medium modified by the removal of the yeast extract and the addition of citrate buffer $(50 \mathrm{mM}, \mathrm{pH}$ 7 ) in place of the distilled water. The medium was then supplemented by potassium tartrate antimonyl trihydrate $\left(\mathrm{C}_{8} \mathrm{H}_{4} \mathrm{~K}_{2} \mathrm{O}_{12} \mathrm{Sb}_{2} \quad 3 \mathrm{H}_{2} \mathrm{O}\right.$ Sigma-Aldrich) with different concentrations, namely, $0,5,10,20$ and $30 \mathrm{mM}$ of $\mathrm{Sb}$. The maximum dose was determined by the minimum biomass quantity required to the realization of the toxicity biomarker analyses. Each flask containing the different metal concentrations ( 0 to $30 \mathrm{mM}$ of $\mathrm{Sb}$ ) was inoculated with $1 \mathrm{~mL}$ of a $24 \mathrm{~h}$ pre-culture containing approximately $4 \times 10^{5} \mathrm{CFU}$. All cultures were performed in triplicate and shaken in a rotary incubator (New Brunswick Scientific, Co., Inc., NJ, USA) at $150 \mathrm{rpm}$ at $30^{\circ} \mathrm{C}$ for $24 \mathrm{~h}$.

Bacterial growth was estimated by measuring the absorbance at $650 \mathrm{~nm}$ for each $\mathrm{Sb}$ concentration in the culture medium. The culture without metalloid (negative control) was considered as $100 \%$ of growth. The growth in the presence of $\mathrm{Sb}$ was then expressed as a percentage by reference to the negative control. The $\mathrm{pH}$ variations before and after fermentation were stabilized by the addition of the citrate buffer.

\section{Enzymatic and MDA Extract Preparation}

Biomass was harvested from liquid batch culture after $24 \mathrm{~h}$ of incubation $\left(30^{\circ} \mathrm{C} / 150 \mathrm{rpm}\right)$ by centrifugation at $8,000 \times \mathrm{g}$ for $15 \mathrm{~min}$ at $4^{\circ} \mathrm{C}$. The resulting cell pellet was washed with sterile deionized water and ground with a mortar under liquid nitrogen. The obtained powder was suspended in $50 \mathrm{mM}$ ice-cold phosphate buffer $(\mathrm{pH} 7)$ containing $0.1 \%(\mathrm{v} / \mathrm{v})$ triton $\mathrm{X}-100$ and $1 \%(\mathrm{w} / \mathrm{v})$ polyvinyl pyrrolidone (PVP). The cellular debris was removed by centrifugation at $10,000 \times \mathrm{g}$ for $15 \mathrm{~min}$ at $4^{\circ} \mathrm{C}$, and the obtained supernatant was used to determine the levels of lipid peroxidation and specific enzyme activities (CAT, POD, APX and SOD). The soluble protein levels were estimated by the procedure of Lowry et al. [17] using bovine serum albumin (BSA) as a standard.

\section{Determining Intracellular $\mathrm{H}_{2} \mathrm{O}_{2}$}

Hydrogen peroxide $\left(\mathrm{H}_{2} \mathrm{O}_{2}\right)$ levels were determined according to the method described by Chakraborty et al. [18]. The biomass was homogenized in an ice bath with $5 \mathrm{~mL} 0.1 \%$ (w/v) trichloroacetic acid (TCA). The homogenate was centrifuged at $12000 \times \mathrm{g}$ for $15 \mathrm{~min}$. $0.5 \mathrm{~mL}$ of the supernatant were added to $0.5 \mathrm{~mL}$ of $10 \mathrm{mM}$ phosphate buffer ( $\mathrm{pH} 7)$ and $1 \mathrm{~mL}$ of $1 \mathrm{M}$ KI. The absorbance was read at $390 \mathrm{~nm}$, and the concentration of $\mathrm{H}_{2} \mathrm{O}_{2}$ was given by a standard curve.

\section{Determining Malondialdehyde (MDA) Content}

The content of malondialdehyde (MDA), the final product of lipid peroxidation, was assayed following Chakraborty et al. [19]. A $0.5 \mathrm{~mL}$ aliquot of the previous extract was added to $1 \mathrm{~mL}$ of $20 \%$ $(\mathrm{w} / \mathrm{v})$ trichloroacetic acid (TCA) and $0.5 \% \quad(\mathrm{w} / \mathrm{v})$ thiobarbituric acid (TBA). The mixture was incubated at $95^{\circ} \mathrm{C}$ for $30 \mathrm{~min}$ and the reaction was stopped by placing the tubes in an ice bath. Centrifugation was carried out for $10 \mathrm{~min}$ at $10,000 \times \mathrm{g}$. The value for nonspecific absorbance of the supernatant at $600 \mathrm{~nm}$ was subtracted from the value at $532 \mathrm{~nm}$. The amount of MDA-TBA complex (red pigment) was calculated using the adjusted absorbance and molar extinction coefficient $155 \mathrm{mM}^{-1} \mathrm{~cm}^{-1}$.

\section{Determining Intracellular Proline Content}

Free proline content was determined by the method cited by Zhang et al. [20]. 0.1g of fresh biomass was ground in an ice bath, to which $2 \mathrm{~mL}$ of $40 \%$ (v/v) methanol were added. After incubation at $85^{\circ} \mathrm{C}$ for $1 \mathrm{~h}$ and cooling to room temperature, $1 \mathrm{~mL}$ of the extracted solution was mixed with $2 \mathrm{~mL}$ of acetic acid, $25 \mathrm{mg}$ of ninhydrin and $1 \mathrm{~mL}$ of a mixture that contained: $120 \mathrm{~mL}$ acetic acid, $300 \mathrm{~mL}$ distilled water and $80 \mathrm{~mL}$ orthophosphoric acid. The homogenate was boiled for $30 \mathrm{~min}$, and subsequently placed in an ice bath to stop the reaction. To allow phases separation, toluene was added to the mixture and shaken vigorously. The intensity of the red color of the upper phase was read at $528 \mathrm{~nm}$. The intracellular proline concentration was determined using the molar extinction coefficient $0.62 \mu \mathrm{M}^{-1} \mathrm{~cm}^{-1}$ and calculated on a fresh weight basis.

\section{Antioxidant Enzyme Activity Measurements}

Catalase (CAT) activity (EC.1.11.1.6) was measured using the method used by Chandrakar et al. [21]. The hydrogen peroxide decomposition was followed by measuring the decrease in absorbance at $240 \mathrm{~nm}$ every minute within the first three minutes of the reaction. The CAT activity was determined using the extinction coefficient $39.4 \mathrm{mM}^{-1} \mathrm{~cm}^{-1}$ and specific activity was given as $\mu \mathrm{M} \mathrm{min}{ }^{-1} \mathrm{mg}^{-1}$ proteins. Peroxidase (POD) activity (EC.1.11.1.7) was assayed by the method described by Benhamdi et al. [14]. The amount of purpurogalin released after the reaction of pyrogallol with $\mathrm{H}_{2} \mathrm{O}_{2}$ was measured at $420 \mathrm{~nm}$. The enzymatic activity corresponded to 0.1 absorbance $\mathrm{min}^{-1} \mathrm{mg}^{-1}$ protein as one unit. Ascorbate peroxidase 
(APX) activity (EC.1.11.1.11) was assayed according to Djébali et al. [22] by measuring the decrease in the absorbance of oxidized ascorbate at $290 \mathrm{~nm}$ $\left(\varepsilon=2.8 \mathrm{mM}^{-1} \mathrm{~cm}^{-1}\right)$. The APX activity was expressed

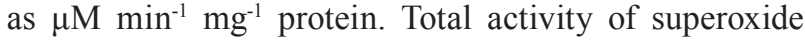
dismutase (SOD) (EC.1.15.1.1) was quantified according to the method reported by Abdalla et al. [23]. One unit of SOD activity was defined as the amount of enzyme required to cause $50 \%$ pyrogallol autooxidation inhibition at $420 \mathrm{~nm}$; it was expressed as $\mathrm{U} \mathrm{mg}^{-1}$ protein.

\section{Statistical Analysis}

The mean of the experimental results $(n=3)$ and their standard errors (SEM) are represented in bar graphs. The significance of the differences between the means is estimated using a variance analysis (ANOVA) followed by Tukey's test. The relationships between all variables analyzed and between those and $\mathrm{Sb}$ concentrations of the medium was tested by the Pearson correlation coefficients (r). The data treatment was carried out using XLStat 2014 software.

\section{Results and Discussion}

\section{Identifying the Antimony-Resistant Endophyte Bacteria}

One hundred and forty-eight bacterial strains were isolated from the roots of $H$. pallidum. The screening revealed that the $\mathrm{H}_{6} \mathrm{R}_{1} \mathrm{~B}$ bacterium is the most resistant to antimony, because it is the only one that was able to grow in the presence of up to $425 \mathrm{mM}$ of $\mathrm{Sb}$, i.e., $51748 \mathrm{mg} / \mathrm{L}$ of $\mathrm{Sb}$. The MIC of this isolate would therefore be $450 \mathrm{mM}$ of $\mathrm{Sb}$. The other isolates showed much lower MICs not exceeding $250 \mathrm{mM}$ of Sb.

The Gram-staining reaction of $\mathrm{H}_{6} \mathrm{R}_{1} \mathrm{~B}$ bacterium showed that this strain is a Gram-negative rodsharp bacteria. According to its morphology, cultural appearance, physiological and biochemical characteristics, using API $20 \mathrm{E}$ strips, the $\mathrm{H}_{6} \mathrm{R}_{1} \mathrm{~B}$ bacterium could be Serratia marcescens (72\%). The amplification, sequencing and alignment of its 16S rRNA gene sequence with GenBank reference sequences had confirmed that this strain is Serratia marcescens with $99 \%$ identity (Fig. 2). Serratia genus was created by Bizio, who chose this name to honor the memory of the celebrated Italian physicist Serafino Serrati. Some strains produce a red pigment, the prodigiosin. The term marcescens, meaning decaying in latin, was used because of pigment's decay and its dissolution into a fluid and viscous matter, which has a mucilaginous appearance upon reaching maturity [24].

Although generally considered a pathogenic microorganism for humans and animals [25], this species is recognized as a rhizobacterium promoting plant growth. Indeed, it has been used to enhance the growth of tropical and medicinal plants, the chaffflower (Achyranthes aspera) [26] and in the induction of phenols and defense enzymes in an Asian medicinal plant, the betelvine [27]. When isolated from flowers of summer squash (Cucurbita pepo), it allowed induction of cold resistance of wheat seeds [28]. Thus, it is not very surprising that this species is an endophyte, which is resistant to a toxic metalloid.

\section{Growth of the Bacterial Endophyte Serratia marcescens}

The effect of the added $\mathrm{Sb}$ on the growth of Serratia marcescens grown on submerged cultivation in the presence of increasing $\mathrm{Sb}$ concentrations is represented in Fig. 3a). S. marcescens growth shows an important gradual decrease with the increase of $\mathrm{Sb}$ concentration in the culture medium. It is significantly and negatively correlated $\left(\mathrm{p}<10^{-3}\right)$ with the metalloid concentration (Table 1). The growth reduction rates are 9\%, 15.5\%, $21.5 \%$ and $38 \%$ relative to the control at concentrations of $5,10,20$ and $30 \mathrm{mM}$ of $\mathrm{Sb}$, respectively. At $30 \mathrm{mM}$ of $\mathrm{Sb}$ the strain still produces $62 \%$ of biomass relative to the growth of the control.

The significant decrease in $S$. marcescens growth according to the increase of $\mathrm{Sb}$ concentrations highlights the toxic effect of this metalloid on this strain. This is also evidenced by the negative and very significant correlation of growth with $\mathrm{Sb}$ concentrations. Such a decrease can be explained by a likely modification of the physiological mechanisms of tested strain in response to $\mathrm{Sb}$ toxicity. Indeed, according to Bahar et al. [29], to Siripornadulsil and Siripornadulsil [30] and to Chakraborty et al. [18], non-lethal metallic amounts ( $\mathrm{Sb}$ in our study) induce a disturbance in the membrane permeability of the bacterial cell and consequently an important loss of essential nutrients for bacterial growth.

Moreover, despite the toxic effect of $\mathrm{Sb}, \mathrm{S}$. marcescens preserved approximately $62 \%$ of its growth at $30 \mathrm{mM}$ of $\mathrm{Sb}$ compared to the control. Such growth for such high concentration, corresponding to $3652.8 \mathrm{mg} / \mathrm{L} \mathrm{Sb}$, could be explained by the prior adaptation of the strain to high Sb levels in the origin area rich with heavy metals - especially antimony. Our results are in agreement with several works, in particular those of Cernansky et al. [31] and Chakraborty et al. [18], who reported that microorganisms isolated from the heavy metal-contaminated environments develop the adaptive ability to sustain themselves in such environments.

\section{Toxicity Biomarkers}

\section{Intracellular $\mathrm{H}_{2} \mathrm{O}_{2}$ Contents}

The intracellular $\mathrm{H}_{2} \mathrm{O}_{2}$ levels of $S$. marcescens (Fig. 3b.) increased slightly at 5 and $10 \mathrm{mM}$ of $\mathrm{Sb}$, 


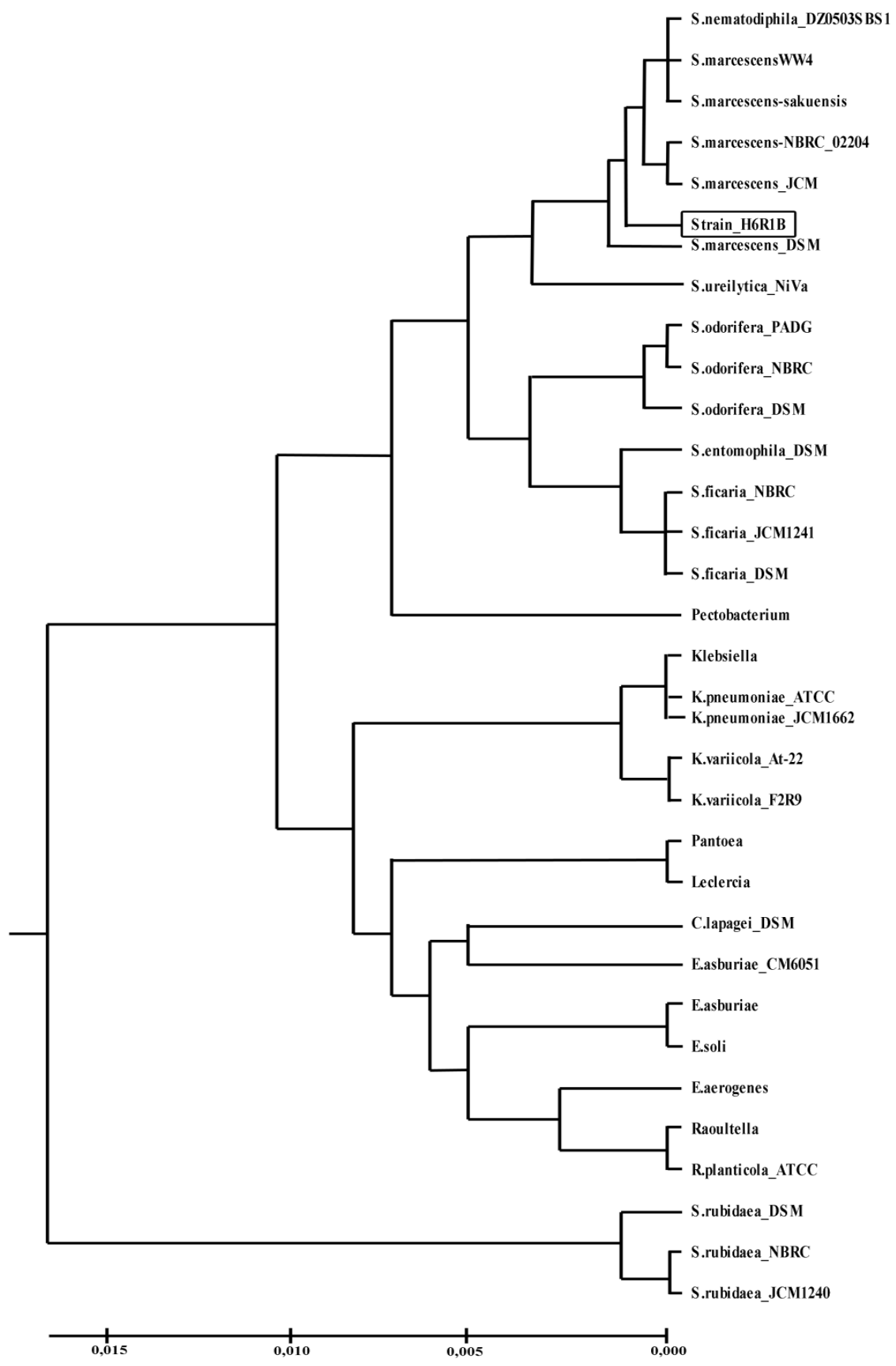

Fig. 2. Phylogenetic tree showing the relationship between $\mathrm{H}_{6} \mathrm{R}_{1} \mathrm{~B}$ bacteria and Serratia marcescens by $16 \mathrm{SrDNA}$ gene analysis.

with an increase of $23.02 \%$ and $45.36 \%$ compared to the control. At 20 and $30 \mathrm{mM}$ of $\mathrm{Sb}$, they show an important and very important increase, reaching respectively $356.5 \%$ and $445 \%$ compared to the control. However, they progress in the opposite direction of the growth rates of $S$. marcescens. Moreover, they are correlated very significantly and positively $\left(\mathrm{p}<10^{-3}\right)$ with $\mathrm{Sb}$ concentrations of the medium, but negatively and very significantly $\left(\mathrm{p}<10^{-3}\right)$ with the strain growth rates (Table 1).

The significant increase in intracellular $\mathrm{H}_{2} \mathrm{O}_{2}$ contents with the gradual increase of $\mathrm{Sb}$ concentrations, and their very significant positive correlation, showed that the increase of $\mathrm{H}_{2} \mathrm{O}_{2}$ in the bacterium is due to
$\mathrm{Sb}$ presence in the medium. Thus, the presence of important $\mathrm{Sb}$ quantities in the medium has induced the formation of reactive species (ROS), of which $\mathrm{H}_{2} \mathrm{O}_{2}$ is one. This latter is a strong oxidant, even at relatively low concentrations. According to Sharma et al. [32], it could cause oxidative damage to the lipid layer of the cell membrane by the peroxidation of polyunsaturated fatty acids and, consequently, disruption of the metabolic function and losses of cellular integrity. Such damages inevitably lead to a decrease in growth, which is evidenced by the very significant negative correlation between the $\mathrm{H}_{2} \mathrm{O}_{2}$ content and $S$. marcescens growth rate. 
Table 1. Pearson correlation coefficients between all analyzed variables and between those and antimony culture medium concentrations; $* \mathrm{p}<0.05, * * \mathrm{p}<10^{-2}, * * * \mathrm{p}<10^{-3}(\mathrm{n}=15)$.

\begin{tabular}{|c|c|c|c|c|c|c|c|c|}
\hline & Growth & $\mathrm{H}_{2} \mathrm{O}_{2}$ & MDA & Proline & CAT & POD & APX & SOD \\
\hline $\mathrm{Sb}(\mathrm{mM})$ & $-0,967 * * *$ & $0,972^{* * *}$ & 0,108 & 0,290 & $0,698^{* *}$ & $-0,121$ & 0,422 & $-0,081$ \\
\hline Growth & 1 & $-0,905^{* * *}$ & $-0,094$ & $-0,233$ & $-0,609 *$ & $-0,121$ & 0,422 & 0,006 \\
\hline $\mathrm{H}_{2} \mathrm{O}_{2}$ & & 1 & 0,026 & 0,295 & $0,727 * *$ & $-0,267$ & 0,286 & $-0,247$ \\
\hline MDA & & & 1 & $0,774 * *$ & $0,536^{*}$ & $0,875^{* * *}$ & $0,850^{* * *}$ & $0,773 * *$ \\
\hline Proline & & & & 1 & $0,744^{* *}$ & $0,594 *$ & $0,760^{* *}$ & $0,507 *$ \\
\hline CAT & & & & & 1 & 0,214 & $0,590^{*}$ & 0,148 \\
\hline POD & & & & & & 1 & $0,825^{* *}$ & $0,959 * * *$ \\
\hline APX & & & & & & & & $0,829 * *$ \\
\hline
\end{tabular}

\section{MDA Contents}

After $24 \mathrm{~h}$ of bacterial growth, the MDA contents increased gradually and significantly $(\mathrm{p}<0.05)$ at 5 and $10 \mathrm{mM}$ of $\mathrm{Sb}$ by $48 \%$ and $121 \%$, respectively, compared to the control. At $20 \mathrm{mM}$ of Sb treatment, a non-significant decrease is observed. Then, at $30 \mathrm{mM}$ of $\mathrm{Sb}$ the MDA content decreases significantly $(\mathrm{p}<0.05)$ with increasing metal stress (Fig. 3c.), and the MDA contents were not correlated with either $\mathrm{Sb}$ contents, growth, or $\mathrm{H}_{2} \mathrm{O}_{2}$ contents (Table 1). However, when the values obtained at $30 \mathrm{mM}$ of $\mathrm{Sb}$ were omitted, the MDA contents become significantly and positively correlated with the $\mathrm{Sb}\left(\mathrm{r}=0.809, \mathrm{p}<10^{-2}, \mathrm{n}=12\right)$ and $\mathrm{H}_{2} \mathrm{O}_{2}$ contents $(\mathrm{r}=0.587, \mathrm{p}<0.05, \mathrm{n}=12)$ and significantly and negatively with growth $\left(\mathrm{r}=-0.885, \mathrm{p}<10^{-2}, \mathrm{n}=12\right)$.

According to Ayala et al. [33], the lipid peroxidation process produces multiple breakdown molecules, such as MDA, which promotes intramolecular or intermolecular protein/DNA crosslinking, which may induce profound alteration in the biochemical properties of biomolecules. Thus, the significant elevation in the MDA content with the rise of $\mathrm{Sb}$ concentrations and the significant and positive correlation of these two parameters of up to $20 \mathrm{mM}$ of $\mathrm{Sb}$, show that the presence of high concentrations of this metalloid in the culture medium can be responsible for the lipid peroxidation of the $S$. marcescens membrane and thus a high MDA production. This one would be responsible for the alteration of the biochemical properties of biomolecules of $S$. marcescens, leading to growth reduction, which is highlighted by the significance and negative correlation of MDA with the growth of the strain up to $20 \mathrm{mM}$ of Sb.

The non-existence of correlation between $\mathrm{Sb}$ and MDA contents, when all values are considered, is related to the significant decrease in MDA content at $30 \mathrm{mM}$ of $\mathrm{Sb}$. This can be explained by the fact that a very high amount of $\mathrm{H}_{2} \mathrm{O}_{2}$ is produced at $30 \mathrm{mM}$ of $\mathrm{Sb}$, causing an important alteration of the strain metabolic functions, which caused the fall of the MDA production itself. This is also reflected in the lack of correlation between
MDA and $\mathrm{H}_{2} \mathrm{O}_{2}$ when all obtained values are introduced. The weakly significant correlation of both variables when obtained values at $30 \mathrm{mM}$ of $\mathrm{Sb}$ are omitted can be explained by the fact that other unmeasured ROS than $\mathrm{H}_{2} \mathrm{O}_{2}$, such as $\mathrm{OH}$ and $\mathrm{O}_{2}{ }^{--}$, are involved in the lipid peroxidation process, of which the MDA is the product.

\section{Intracellular Proline Contents}

The obtained results (Fig. 3d) show that the proline contents of the fresh bacterial biomass increased significantly $(p<0.05)$ with the increase in $\mathrm{Sb}$ concentrations. At 5, 10 and $20 \mathrm{mM}$ of $\mathrm{Sb}$, this increase is approximately $59.26 \%, 65.39 \%$ and $114.47 \%$ respectively, compared to the control. However, a decrease in the proline content at $30 \mathrm{mM}$ of $\mathrm{Sb}$ is noticed with about $39.77 \%$ compared to the maximum value. The proline contents were significantly and positively $(\mathrm{p}<0.05)$ correlated with MDA contents, CAT, POD, APX, and SOD activities, but they were not correlated with either $\mathrm{Sb}$ concentrations, growth, or $\mathrm{H}_{2} \mathrm{O}_{2}$ contents (Table 1). However, when we omitted the values obtained at $30 \mathrm{mM}$ of $\mathrm{Sb}$, thus $\mathrm{n}=12$, the proline contents became correlated very significantly and positively with the contents of $\mathrm{Sb}\left(\mathrm{r}=0.907, \mathrm{p}<10^{-3}\right)$ and $\mathrm{H}_{2} \mathrm{O}_{2}\left(\mathrm{r}=0.835, \mathrm{p}<10^{-2}\right)$ and very significantly and negatively to growth $\left(\mathrm{r}=-0.899, \mathrm{p}<10^{-3}\right)$.

Proline is an amino acid that acts as a chelating agent for some heavy metals; it reduces the harmful effects of ROS by inhibiting lipid peroxidation because it is a scavenger of the ROS and other free radicals [34]. Thus, its significant increase as a function of $\mathrm{Sb}$ concentrations of up to $20 \mathrm{mM}$ of $\mathrm{Sb}$ and its positive and significant correlation with $\mathrm{MDA}$ and $\mathrm{H}_{2} \mathrm{O}_{2}$ contents, show that its production was induced by the presence of elevated concentrations of $\mathrm{Sb}$ in order to fight against lipid peroxidation caused by $\mathrm{H}_{2} \mathrm{O}_{2}$ toxicity. Furthermore, the negative correlation of proline with growth, for concentrations below $30 \mathrm{mM}$ of $\mathrm{Sb}$, suggests that the reduction of growth, due to Sb toxicity, would be the triggering factor of proline production. Therefore, 


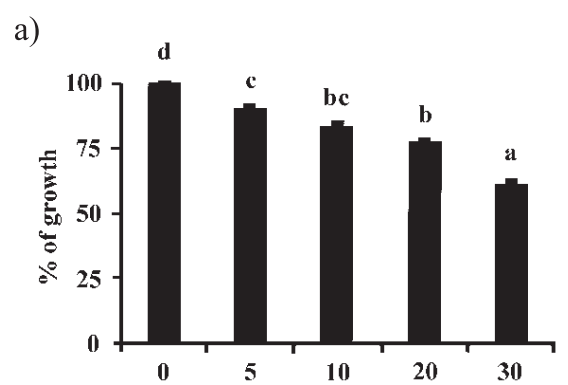

c)
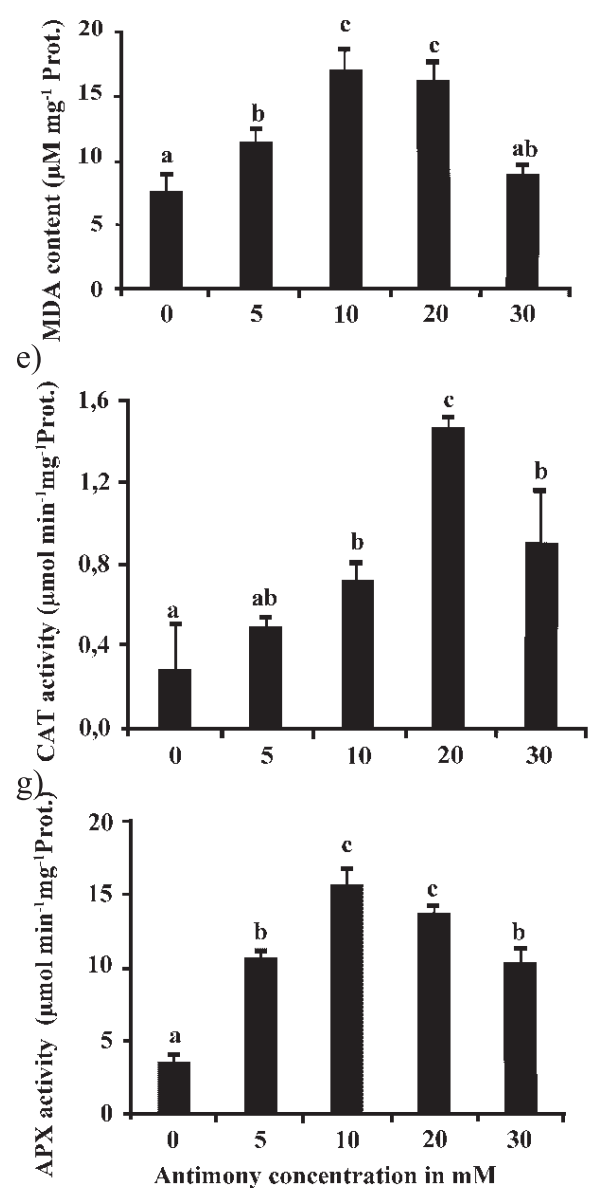

b)

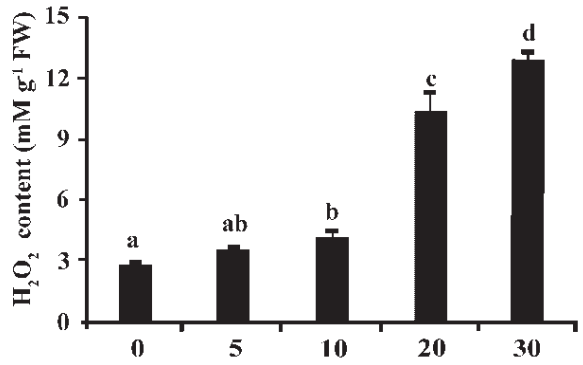

d)

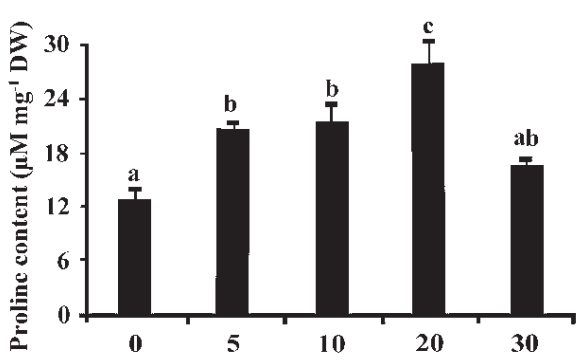

f)

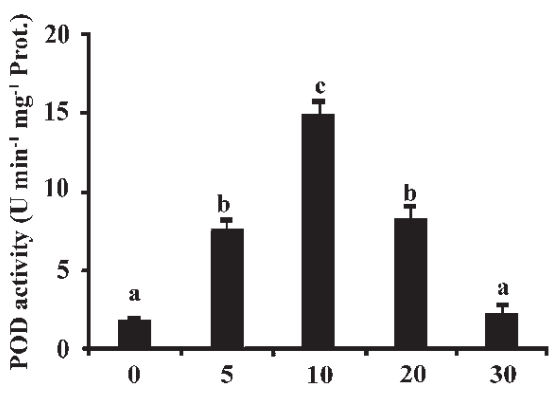

h)

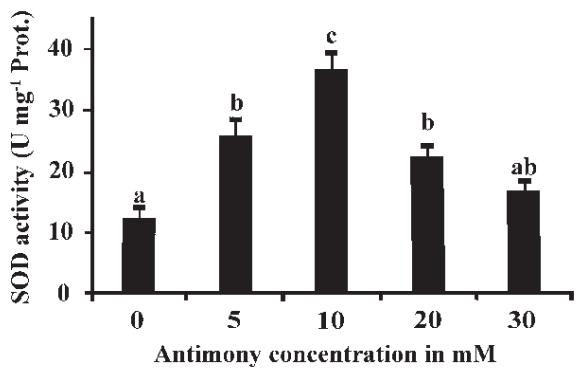

Fig. 3. Antimony effect on physiological parameters of the endophytic Serratia marscesens isolated from Hedysarum pallidum roots; growth percentage a), $\mathrm{H}_{2} \mathrm{O}_{2}$ contents b), MDA contents c), proline contents d), and the activities of CAT e), POD f), APX g), and SOD h) measured according to Sb concentrations in millimolar $(\mathrm{mM})$; values represent means $\pm \mathrm{SEM}(\mathrm{n}=3)$, and different letters discriminate statistical differences between the measured parameters at the different $\mathrm{Sb}$ concentrations (using ANOVA followed by Tukey's test, $\mathrm{p}<0.05)$.

proline would have been produced by $S$. marcescens to counteract the toxicity of the metalloid and reduce its deleterious effects on the metabolism and to prevent an important decrease in the growth of the bacteria. The absence of correlation with these same variables and with growth, when the obtained values at $30 \mathrm{mM}$ of $\mathrm{Sb}$ are taken into account, can be explained by the sharp decrease in the proline content at this concentration. This decrease indicates a disruption in the cellular detoxification mechanism by proline at high antimony concentrations. These findings are in agreement with previous results reported by Anki and Leblon [35], who found that proline was the main response of Corynebacterium glutamicum when it is exposed to hyperosmotic stress conditions. Significant and positive correlations of proline with CAT, POD, APX, and SOD suggest that proline production would be related to the induction of these enzyme activities. In fact, according to the works of Öztürk and Demir [36] on plants, CAT and POD would be activated by proline, which also acts as a protector of the activity of these enzymes. This could be the case for $S$. marcescens not only for CAT and POD but also for APX and SOD. 


\section{Antioxidant Enzyme Activities}

A progressive and significant increase $(p<0.05)$ in CAT activity was observed with the increase in $\mathrm{Sb}$ concentrations of up to $20 \mathrm{mM}$ of Sb (Fig. 3e). The rise of this activity was about 1.8-fold, 2.6-fold and 5.25-fold at 5,10 and $20 \mathrm{mM}$ of $\mathrm{Sb}$ respectively, in comparison to the control. However, a significant decrease $(p<0.05)$ in CAT activity was observed at $30 \mathrm{mM}$ of Sb. The activity of this enzyme is significantly and positively correlated with $\mathrm{Sb}, \mathrm{H}_{2} \mathrm{O}_{2}$, proline and MDA contents and APX activity $(\mathrm{p}<0.05)$, but significantly and negatively with growth $(\mathrm{p}<0.05)$ (Table 1$)$.

APX activity (Fig. 3g) reached its maximum at 10 and $20 \mathrm{mM}$ of $\mathrm{Sb}$ with a significant increase $(\mathrm{p}<0.05)$ of about 4.33-fold over control. A significant decrease $(p<0.05)$ in enzymatic activity was observed at $30 \mathrm{mM}$ $\mathrm{Sb}$. However, this apparent decrease in enzyme activity was still superior to the control by 2.88 -fold. The APX activity was correlated, significantly and positively $(\mathrm{p}<0.05)$, with all measured variables except growth, $\mathrm{Sb}$ and $\mathrm{H}_{2} \mathrm{O}_{2}$ contents (Table 1). When one withdraws the obtained data at $30 \mathrm{mM}$, therefore $\mathrm{n}=12$, the APX activity becomes significantly and positively correlated to $\mathrm{Sb}$ concentrations $\left(\mathrm{r}=0.753, \mathrm{p}<10^{-2}\right)$ and significantly and negatively to growth $\left(\mathrm{r}=-0.876, \mathrm{p}<10^{-2}\right)$, but not to the $\mathrm{H}_{2} \mathrm{O}_{2}$ content. However, when only data obtained for concentrations lower than $20 \mathrm{mM} \mathrm{Sb}$ are taken into account $(\mathrm{n}=9)$, the correlations between APX activity and $\mathrm{H}_{2} \mathrm{O}_{2}$ contents become very significant: $\mathrm{r}=-0.953, \mathrm{p}<10^{-3}$.

Significant increases in CAT and APX activities as a function of $\mathrm{Sb}$ concentrations prove that the presence of this toxicant in the culture medium has induced their activities in $S$. marcescens. The production of these two enzymes has been increased by the bacterium to fight against lipid peroxidation caused by $\mathrm{H}_{2} \mathrm{O}_{2}$ generated by $\mathrm{Sb}$ toxicity. Indeed, both use hydrogen peroxide $\left(\mathrm{H}_{2} \mathrm{O}_{2}\right)$ as a substrate to yield water $\left(\mathrm{H}_{2} \mathrm{O}\right)$ and oxygen $\left(\mathrm{O}_{2}\right)$. This reaction is essential for the detoxification of the ROS generated during stress conditions. It protects lipids, proteins and cellular nucleic acids from damage caused by $\mathrm{H}_{2} \mathrm{O}_{2}$ and other ROS [32]. Such a role is confirmed by the positive and significant correlations of both enzyme activities with the MDA contents for all $\mathrm{Sb}$ concentrations, and with the $\mathrm{H}_{2} \mathrm{O}_{2}$ contents of up to $30 \mathrm{mM}$ of $\mathrm{Sb}$, for CAT, and up to $10 \mathrm{mM}$ of $\mathrm{Sb}$ for APX. Such a correlation can be explained by the fact that under oxidative stress conditions, excess generation of $\mathrm{H}_{2} \mathrm{O}_{2}$ may cause the depletion of reduced ascorbate, which inactivates APX, as that is reported by Watanabe and Nakajima [37]. According to Mizuno et al. [38] CAT and APX cooperate for protection against $\mathrm{H}_{2} \mathrm{O}_{2}$ generated by abiotic stress, which explains the positive and significant correlation between these two enzymes.

However, according to Watanabe and Nakajima [37] considering the enzyme stability under oxidative stress conditions, CAT is much superior to APX as a stressresistant enzyme. This would explain the fact that
CAT, unlike APX, is correlated with $\mathrm{H}_{2} \mathrm{O}_{2}$ contents up to $30 \mathrm{mM}$ of $\mathrm{Sb}$. Nevertheless, the intracellular $\mathrm{H}_{2} \mathrm{O}_{2}$ hyperproduction at $30 \mathrm{mM}$ of $\mathrm{Sb}$ by isolated strain, due to the excess of the metalloid, would have also resulted in the significant reduction of CAT activity. Indeed, Polidoros and Scandalios [39] have also reported that CAT activity is directly regulated by $\mathrm{H}_{2} \mathrm{O}_{2}$ concentration whose high accumulation may reduce the activity of this enzyme. Negative and significant correlations of CAT and APX activities with bacterial growth mean that the activities of these enzymes increase as growth decreases. This correlation is explained by the fact that the decrease in growth is caused by the lipid peroxidation of the cell membranes, generated by the increase of intracellular $\mathrm{H}_{2} \mathrm{O}_{2}$ and thus the increase in the activities of the two enzymes. Benhamdi et al. [16] had also found a significant increase in CAT and APX activities of Hedysarum pallidum roots growing in the most polluted areas by $\mathrm{Sb}$. It is therefore quite probable that $S$. marcescens, endophyte of $H$. pallidum roots, had an impact on the production of both enzymes of this plant, allowing it to resist the stress of high $\mathrm{Sb}$ concentrations. In addition, according to Hamilton et al. [40], root endophytes may increase host tolerance to various stresses via mechanisms involving reactive oxygen species and antioxidants.

It appears that the POD and SOD activities have similar bar graphs (Figs 3f, h). Indeed, their activities increased significantly $(\mathrm{p}<0.05)$ up to $10 \mathrm{mM}$ of $\mathrm{Sb}$, where they reach their highest levels: 4.5-fold and 8 -fold, respectively, than the control. Then they decreased significantly $(\mathrm{p}<0.05)$ while remaining higher than those of the control. Both POD and SOD activities were positively correlated between them and they were correlated very significantly $\left(p<10^{-3}\right)$ to MDA, APX activity, and proline. They only become correlated significantly and negatively with growth once the values obtained at $30 \mathrm{mM}$ of $\mathrm{Sb}$ are subtracted: $\mathrm{r}=-0.882$ $\left(\mathrm{p}<10^{-2}\right)$ for POD and $\mathrm{r}=-0.557(\mathrm{p}<0.05)$ for SOD. When the data obtained for concentrations greater than $10 \mathrm{mM}$ of $\mathrm{Sb}$ are subtracted $(\mathrm{n}=9)$, the correlations between the SOD and POD activities and the $\mathrm{Sb}$ and $\mathrm{H}_{2} \mathrm{O}_{2}$ contents and CAT activity become significant to very significant: respectively, $r=0,993\left(\mathrm{p}<10^{-3}\right)$; $\mathrm{r}=0,973\left(\mathrm{p}<10^{-3}\right) ; \mathrm{r}=0,827\left(\mathrm{p}<10^{-2}\right)$ for POD and $\mathrm{r}=0,980\left(\mathrm{p}<10^{-3}\right) ; \mathrm{r}=0,955\left(\mathrm{p}<10^{-3}\right)$ and $\mathrm{r}=0,838$ $\left(\mathrm{p}<10^{-3}\right)$ for SOD.

Superoxide dismutase (SOD) is another key enzyme that protects cells against oxidative stress by catalyzing the dismutation of superoxide radical $\left(\mathrm{O}_{2}^{-}\right)$to oxygen $\left(\mathrm{O}_{2}\right)$ and hydrogen peroxide $\left(\mathrm{H}_{2} \mathrm{O}_{2}\right)$ [32]. This latter is itself a powerful oxidant which is broken down then by POD, APX and CAT. Thus, the significant increases of SOD and POD activities with the Sb concentrations and their very significant and positive correlations with these last, up to $10 \mathrm{mM}$ of $\mathrm{Sb}$, prove, as for CAT and APX, that the presence of this metalloid in the culture medium has induced their activities in $S$. marcescens. The decrease in SOD and POD activities, after $10 \mathrm{mM}$ 
of $\mathrm{Sb}$, can be explained, as for APX, by the sensitivity of these enzymes to high $\mathrm{H}_{2} \mathrm{O}_{2}$ levels [41]. This explains the significant and positive correlations between these three enzymes and the fact that SOD and POD are only correlated with CAT for values below $10 \mathrm{mM}$ of $\mathrm{Sb}$, which is less sensitive to high $\mathrm{H}_{2} \mathrm{O}_{2}$ levels. In the work of Benhamdi et al. [16] the activities of SOD and POD of $H$. pallidum roots were all the higher as soil $\mathrm{Sb}$ concentrations were higher. But SOD and POD activities of $S$. marcescens were reduced when $\mathrm{Sb}$ concentrations were higher in medium. This could be explained by the fact that, according to Welinder [42], both enzymes differ from those of bacteria.

\section{Conclusions}

Hedysarum pallidum Desf., a Fabacea of the semiarid steppic regions, growing on antimony mining spoils and accumulator of this metalloid, has been found to harbor several endophytic bacteria within its roots. Among these, one strain was able to grow up to $425 \mathrm{mM}$ of $\mathrm{Sb}$ in the medium. It was identified as Serratia marcescens by sequencing and comparison of its 16S rRNA gene sequence with GenBank data.

The presence of excessive $\mathrm{Sb}$ concentrations, corresponding to $3652.8 \mathrm{mg} / \mathrm{L}$, in $S$. marcescens culture medium, caused high accumulation of hydrogen peroxide in the bacteria cells, leading to lipid peroxidation and therefore a decrease in its growth. This latter remained relatively high compared to the control, despite the toxicity of the medium, and reflects an important adaptation of the isolated strain to excessive $\mathrm{Sb}$ concentrations. This adaptation also resulted in the ability of the strain to fight ROS by inducing increased production of proline and antioxidant enzymes, such as CAT and APX, at the most excessive $\mathrm{Sb}$ doses. The induction of $\mathrm{SOD}$ and POD activities, very sensitive enzymes to $\mathrm{H}_{2} \mathrm{O}_{2}$ excess, up to $\mathrm{Sb}$ concentrations reaching levels of $1216.6 \mathrm{mg} / \mathrm{L}$, is another proof of the adaptation of $S$. marcescens to $\mathrm{Sb}$ toxicity. Correlations show that the strain implements, at the same time, its antioxidant molecules to fight the antimony stress up to the threshold of $1216.6 \mathrm{mg} / \mathrm{L} \mathrm{Sb}$, but when this threshold is exceeded only the least sensitive molecules are involved, namely proline, CAT and APX.

The strain's ability to produce a sufficient biomass up to $3652.8 \mathrm{mg} / \mathrm{L} \mathrm{Sb}$ in the culture medium and to produce high levels of antioxidant biomarkers attests of its high resistance to excessive levels of antimony. Such an ability, similar to that of its host, suggests that $S$. marcescens is involved in the aptitude of its host, Hedysarum pallidum, to grow on the mining spoils and to accumulate antimony. This could make Serratia marcescens, alone or associated with its plant host, a potential candidate for bioremediation of antimonycontaminated soils.

\section{Acknowledgements}

This work was supported by the Algerian Ministry of Higher Education and Scientific Research.

\section{Conflict of Interest}

The authors declare no conflict of interest.

\section{References}

1. ZHOU Y., REN B., HURSTHOUSE A., ZHOU S. Antimony ore tailings: Heavy metals, chemical speciation, and leaching characteristics. Polish Journal of Environmental Studies, 28, 1, DOI: 10.15244/pjoes/85006, 2019.

2. PIERART A., SHAHID M., SÉJALON DELMAS N., DUMAT C. Antimony bioavailability: Knowledge and research perspectives for sustainable agricultures. Journal of Hazardous Materials, 289, 219, 2015.

3. MUBARAK H., LI-YUAN CHAI L-Y., MIRZAN., YANG Z-H., PERVEZ A., TARIQ M., SHAHEEN S., MAHMOOD Q. Antimony (Sb) _ pollution and removal techniques _ critical assessment of technologies. Toxicological and Environmental Chemistry, 97,1296, 2015.

4. DENG Z., CAO L., HUANG H., JIANG X., WANG W., SHI Y., ZHANG R. Characterization of Cd- and $\mathrm{Pb}$ - resistant fungal endophyte Mucor sp. CBRF59 isolated from rapes (Brassica chinensis) in metal contaminated soils. Journal of Hazardous Materials, 185,717, 2011.

5. SRIVASTAVA S., VERMA P.C., CHAUDHRY V., SINGH N., ABHILASH P.C., KUMAR K.V., SHARMA N., SINGH N. Influence of inoculation of arsenic-resistant Staphylococcus arlettae on growth and arsenic uptake in Brassica juncea (L.) Czern. Var. R-46. Journal of Hazardous Materials, 262, 1039, 2013.

6. WEVAR OLLER A.L., TALANO M.A., AGOSTINI E. Screening of plant growth-promoting traits in arsenicresistant bacteria isolated from the rhizosphere of soybean plants from Argentinean agricultural soil. Plant Soil, 369, 93, 2013.

7. DAS S., JEAN J.S., KAR S., LIU C.C. Changes in bacterial community structure and abundance in agricultural soils under varying levels of arsenic contamination. Geomicrobiology Journal, 30, 635, 2013.

8. IQBAL S., HAMEED S., SHAHID M., HUSSAINE K., AHMAD N., NIAZ M. In vitro characterization of bacterial endophytes from tomato (Solanum lycospermum L.) for beneficial traits. Applied Ecology and Environmental Research, 16, 1037, 2018.

9. YASIN N.A., KHAN W.U., AHMAD S.R., AHMAD A., AKRAM W., IJAZ M. Role of Acinetobacter sp. CS9 in Improving Growth and Phytoremediation Potential of Catharanthus longifolius under Cadmium Stress. Polish Journal of Environmental Studies, 28, 1, DOI: 10.15244/ pjoes/80806, 2019.

10. MA Y., RAJKUMAR M., ZHANG C., FREITAS H. Beneficial role of bacterial endophytes in heavy metal phytoremediation. Journal of Environmental Management, 174, 14, 2016. 
11. GUO H., LIU Z., DING S., HAO C., XIU W., HOU W. Arsenate reduction and mobilization in the presence of indigenous aerobic bacteria obtained from high arsenic aquifers of the Hetao basin, Inner Mongolia. Environmental Pollution, 203,50, 2015.

12. SELVANKUMAR T., RADHIKA R,. MYTHILI R., ARUNPRAKASH S., SRINIVASAN P., GOVARTHANAN M., HYUNOOK K. Isolation, identification and characterization of arsenic transforming exogenous endophytic Citrobacter sp. RPT from roots of Pteris vittata. 3 Biotech, 7, 264, 2017.

13. RACHED-MOSBAH O., GARDOU C. Soil-plant relationship in pastoral areas with a rich antimony substrate: example of Jebel Hamimat (Algeria). Phytosociological Symposium XVI: Phytosociology and pastoralism, Paris, 307, 1988 [In French].

14. BENHAMDI A., BENTELLIS A., RACHED O., LAING G.D., MECHAKRA A. Effects of antimony and arsenic on antioxidant enzyme activities of two steppic plant species in an old antimony mining area. Biological Trace Element Research, 158, 96, 2014.

15. DOMBROWSKI J.E., HOLLENBECK V.G., MARTIN R.C. Isolation and Identification of Bacterial Endophytes from Grasses along the Oregon Coast. American Journal of Plant Sciences , 8, 574, 2017.

16. SEN S.K., RAUTA S., DORA T.K., MOHAPATRA P.K.D. Contribution of hot spring bacterial consortium in cadmium and lead bioremediation through quadratic programming model. Journal of Hazardous Materials, 265, 47, 2014.

17. LOWRY O.H., ROSEBROUGH N.J., FARR A.L., RANDALL R.J. Protein measurement with the Folin phenol reagent. Journal of Biological Chemistry, 193, 265, 1951.

18. CHAKRABORTY S., MUKHERJEE A., KHUDABUKHSH A.R., DAS T.K. Cadmium-induced oxidative stress tolerance in cadmium resistant Aspergillus foetidus: its possible role in cadmium bioremediation. Ecotoxicology and Environmental Safety, 106, 46, 2014.

19. CHAKRABORTY S., MUKHERJEE A., DAS T.K. Biochemical characterization of a lead-tolerant strain of Aspergillus foetidus: An implication of bioremediation of lead from liquid media. International Biodeterioration and Biodegradation, 84, 134, 2012.

20. ZHANG L., XIAO S., LI W., FENG W., LI J., WU Z., GAO X., LIU F., SHAO M. Overexpression of a Harpin-encoding gene hrf1 in rice enhances drought tolerance, Journal of Experimental Botany, 62, 4229, 2011.

21. CHANDRAKAR V., DUBEY A., KESHAVKANT S. Modulation of antioxidant enzymes by salicylic acid in arsenic exposed Glycine $\max$ L., Journal of Soil Science and Plant Nutrition, 16, 662, 2016.

22. DJEBALI N., MHADHBI H., LAFITTE C., DUMAS B., ESQUERRE-TUGAYE M.T., AOUANI M. E., JACQUET C. Hydrogen peroxide scavenging mechanisms are components of Medicago truncatula partial resistance to Aphanomyces euteiches. European Journal of Plant Pathology, 131, 559, 2011.

23. ABDALLA A.N., ALMALIKI W.H., MUKHTAR M.H., ANWAR F., SHAHID I., MENSHAWI S.A., ALSULIMANI T.S. Ameliorative influence of dietary dates on doxorubicin-induced cardiac toxicity. Pharmacology and Pharmacy, 7, 343, 2016.

24. MERLINO C.P. Bartolomeo Bizio's Letter to the most Eminent Priest, Angelo Bellani, Concerning the
Phenomenon of the Red Colored Polenta. Journal of Bacteriology, 9 (6), 527, 1924.

25. OCHIENG J. B., BOISEN N., LINDSAY B., SANTIAGO A., OUMA C., OMBOK M., FIELDS B., STINE O. C., J. P NATARO. Serratia marcescens is injurious to intestinal epithelial cells, Gut Microbes, 5, 729, 2014.

26. DEVI K.A., PANDEY P., SHARMA G.D. Enhances the Growth of Achyranthes aspera L., a Medicinal Plant. Hayati Journal of Biosciences, 23, 173, 2016.

27. LAVANIA M., CHAUHAN P.S., CHAUHAN S.V.S., SINGH H.B., NAUTIYAL C.S. Induction of Plant Defense enzymes and phenolics by treatment with plant growth-promoting rhizobacteria Serratia marcescens NBRI1213. Current Microbiology, 52, 363, 2006.

28. SELVAKUMAR G., MOHAN M., KUNDU S., GUPTA A.D., JOSHI P., NAZIM S., GUPTA H.S. Cold tolerance and plant growth promotion potential of Serratia marcescens strain SRM (MTCC 8708) isolated from flowers of summer squash (Cucurbitapepo). Letters in Applied Microbiology, 46, 171, 2008.

29. BAHAR M.M., MEGHARAJ M., NAIDU R. Kinetics of arsenite oxidation by Variovorax sp. MM-1 isolated from a soil and identification of arsenite oxidase gene. Journal of Hazardous Materials, 262, 997, 2013.

30. SIRIPORNADULSIL S., SIRIPORNADULSIL W. Cadmium-tolerant bacteria reduce the uptake of cadmium in rice: Potential for microbial bioremediation. Ecotoxicology and Environmental Safety, 94, 94, 2013.

31. CERNANSKY S., URIK M., SEVC J., LITTERA P., HILLER E. Biosorption of arsenic and cadmium from aqueous solutions. African Journal of Biotechnology, 6,1932, 2008

32. SHARMA P.,1 JHA A.B., DUBEY R.S., PESSARAKLI M. Reactive oxygen species, oxidative damage, and antioxidative defense mechanism in plants under stressful conditions, Journal of Botany, Volume 2012.

33. AYALA A.F., MUÑOZ M., ARGÜELLES S. Lipid Peroxidation: Production, Metabolism, and Signaling Mechanisms of Malondialdehyde and 4-Hydroxy-2 Nonenal. Oxidative Medicine and Cellular Longevity, Volume 2014, ID 360438.

34. HAYAT S., HAYAT Q., ALYEMENI M. N., WANI A. S., PICHTEL J., AHMAD A. Role of proline under changing environments. Plant Signaling and Behavior, 7, 1, 2012.

35. ANKI S., LEBLON G. Genetic and Biochemical study of proline biosynthesis regulation during the hyperosmotic stress response of Corynebacterium glutamicum. Doctoral Thesis, University Paris 11, Orsay, France, 1996.

36. ÖZTÜRK L., DEMIR Y. In vivo and in vitro protective role of proline. Plant Growth Regulation 38 (3), 259, 2002.

37. WATANABE Y., NAKAJIMA H. Peptide, protein and enzyme design, Chapter twenty - Creation of a thermally tolerant peroxidase. Methods in Enzymology, 580, 2, 2016.

38. ANJUM N.A., SHARMA P., GILL S.S., HASANUZZAMAN M., KHAN E.A., KACHHAP K., MOHAMED A.A, THANGAVEL P., DEVI G.D., VASUDHEVAN P., SOFO A., KHAN N.A., MISRA A.N., LUKATKIN A.S., SINGH H.P., PEREIRA E., TUTEJA N. Catalase and ascorbate peroxidase, representative $\mathrm{H}_{2} \mathrm{O}_{2}$-detoxifying heme enzymes in plants. Environmental Science and Pollution Research, 23, 19002, 2016.

39. POLIDOROS A.N., SCANDALIOS J.G. Role of hydrogen peroxide and different classes of antioxidants in the regulation of catalase and glutathione S- transferase gene expression in maize (Zea mays L.). Physiologia Plantarum, 106, 112, 1999. 
40. HAMILTON C.E., GUNDEL P.E., HELANDER M., SAIKKONEN K. Endophytic mediation of reactive oxygen species and antioxidant activity in plants. Fungal Diversity, 54, 1, 2012.

41. VALDERRAMA B., AYALA M., VAZQUEZ-DUHALT $R$. Suicide inactivation of peroxidases and the challenge of engineering more robust enzymes. Chemistry and Biology, 9, 555, 2002.

42. WELINDER K.G. Superfamily of plant, fungal and bacterial peroxidases. Current Opinion in Structural Biology, 2, 388, 1992. 